\title{
The Politics of Climate Change Coordination: The COP21 Goals I, II, III
}

\author{
Jan-Erik Lane \\ Public Policy Institute, Belgrade, Serbia \\ Email: janeklane@gmail.com
}

How to cite this paper: Lane, J.-E. (2017) The Politics of Climate Change Coordination: The COP21 Goals I, II, III. Open Journal of Political Science, 7, 421-431. https://doi.org/10.4236/ojps.2017.73033

Received: July 3, 2017

Accepted: July 23, 2017

Published: July 26, 2017

Copyright $\odot 2017$ by author and Scientific Research Publishing Inc. This work is licensed under the Creative Commons Attribution International License (CC BY 4.0).

http://creativecommons.org/licenses/by/4.0/

\begin{abstract}
International political coordination in the UNFCCC or G20 runs with a basic insufficiency, making it too weak to respond to the climate change challenge that could bring about a worst case scenario for mankind. Scholars have shown that the UN climate decision-making is manipulated by self-interests from the major powers (Conca, 2015; Vogler, 2016). The Sachs' ideas (2015) of using climate change policy-making to solve other problems like poverty, global redistribution of wealth and stopping general environment degradation make matters just more complicated, resulting in massive transaction costs and likely policy failures. The likelihood of disaster is on the increase, which is why solar energy parks must both replace lots of fossil fuel and wood coal energy as well as provide for the planned strong increased demand for energy.
\end{abstract}

\section{Keywords}

International Governance: UNFCCC, COP23, Global Warming Theory (GWT), Decarbonisation, COP21 Goals: I, II, III, Politics: Implementation Gap, Game Strategies, Common Pool Regime (CPR) Defection, Solar Power Plants (Ouarzazate Size)

\section{Introduction}

The UNFCCC holds a new meeting this fall in Bonn with host country Fiji-the COP23. It has to find a way forward towards the implementation of the COP21 Treaty, although there is already one defection. The islands of Fiji fear of course the sea level rise attending global warming, as there is now a set of islands becoming inhabitable in the Pacific Ocean, e.g. Tuvalu. But the dangers involved in the global warming process concern all countries on the globe in various forms of risks, immense one in reality.

Political scientist Herman Kahn showed in 1962 by Thinking of the Unthinkable that one can scientifically theorize future scenarios with the inter alia one 
terrible outcome, namely the elimination of the human species. Nuclear deterrent has proved effective against this result, with the possible exception of North Korea (Kahn, 1962). But its leader knows that if the country hurts surrounding nations, it will suffer a terrible punishment. Global warming is different, as there is no efficient halting process in place.

Global warming theory (GWT) has come of age. It entails the possibility of a process of continuous warming of the globe until irreversibility is arrived at. Then, humanity is finished forever, as Mother Earth enters a new stage in its giant evolutionary path over hundreds of millions of years. What must be done by international coordination is to set up and operate a common pool regime (CPR) that is capable to halt this climate change process in the 21st century, and maybe reverse it. Is the UNFCCC framework this CPR? I doubt that.

\section{Outline of the Theory of Global Warming (GWT)}

One may distinguish between two parts in GWT, one much developed set of hypotheses bout the natural sciences' contribution to understanding climate change, and one less developed set of hypotheses about the difficulties in engaging in collective action, like the common pool regime (CPR) for decarbonisation. The most ominous warning about the dangers of climate change came very recently from world star physicist Stephen Hawking.

\section{a) Natural sciences}

The first steps towards GWT were developed by Swedish chemist Arrhenius around 1895, suggesting that a doubling of $\mathrm{CO}_{2} \mathrm{ppm}$ could result negatively in a 5 degree Celcius increase in global average temperature (Arrhenius, 1961). It was an exaggerated calculation for 1900, but now it would not too far off the worst scenario for the 21st century, according to UN expertise. A positive anticipation of the global warming mechanism was done by famous mathematician Joseph Fourier in the early $19^{\text {th }}$ century, arguing that without the $\mathrm{CO}_{2}$ layer the Earth would be too cold!

When Stephen Schneider published Global Warming in 1989 and propagated his views in Climate Change journal, GWT started to receive wide attention, no doubt strengthened by the work of C. D. Keeling in measuring $\mathrm{CO}_{2}$ ppm globally. Moreover, techniques for viewing the $\mathrm{CO}_{2}$ layer were developed, increasing the attention to climate change. The UN reacted with creating a few bodies to look into the changes going on, one of which was the COP framework, or UNFCCC.

In the 1990s, economists jumped in besides the natural scientists, worried about the future costs of this transformation of the atmosphere. On the one hand, Kaya and associates (1998) presented a model that explained $\mathrm{CO}_{2}$ : $\mathrm{s}$ with energy and energy intensity of GDP. On the other hand, Stern (2007) called global warming the largest externality in human history, calling for international governance in order to stem the growth of greenhouse gases. Stern outlined a number of activities aimed at reducing $\mathrm{CO}_{2}$ emissions, promising also a Super Fund to channel money from rich advanced nations to poor countries and de- 
veloping economies. As little has been done through the UN system of meetings and agencies up to date, Stern (2015) later asked: "What are we waiting for?"

All theories need severe tests and empirical corroboration (Popper, 1962). When the polar ice mountains began to collapse, it seemed decisive evidence for the global warming theory. Other important test implications like glacier retreats everywhere, ocean warming and acidification as well as desertification in Africa also gave support for global warming theory. Denials of climate change appear more and more unfounded, although it is true that more of $\mathrm{CO}_{2}$ may benefit some fauna or environment niches.

\section{b) Political and social sciences}

The part of GWT analyzing the coordination efforts within the UNFCCC as well as the different country responses to climate change is far less developed than the natural sciences' part. One finds practically nothing in the UNFCCC documents about the principal problems in large scale international governance, like e.g. defection. One may speak of two currents of social science theory that are highly relevant for GWT:

1) Implementation theory: In the discipline of public administration and policymaking, some ideas about the so-called "implementation gap" - Wildavsky's hiatus - are highly relevant to the COP21 project (Pressman \& Wildavsky, 1973, 1984). The COP21 has three main objectives: halt $\mathrm{CO}_{2}$ increases by 2018-2020 (GOAL I), decrease $\mathrm{CO}_{2}$ emissions considerable by 2030 (GOAL II) and achieve full decarbonistion by 2070-80 (GOAL III).

Interestingly, Wildavsky (1997) himself completely rejected GWT-"the mother of environment scares". He was influenced by economist Simon, who rejected environmentalism in general (Simon, 2002), arguing that the normal price system did not indicate that natural resources were running out or becoming scarce.

But how are the COP21 GOALS to be implemented? No one knows, because COP21 has neglected what will happen after the major policy decision. The COP21 project outlines many years of policy implementation to reach decarbonisation, but which are the policy tools and the global funding-SUPER Fund?

2) Game theory: A common pool regime, or CPR is vulnerable to the strategy of reneging, as analyzed theoretically in the discipline of game theory. The relevant game for the CPR is the PD game, where the sub game perfect Nash equilibrium is defection in a finite version of this game (Dutta, 1999). This is not recognized by Ostrom (1990) in her too optimistic view about the viability of CPR: s. It is definitely not the case that Ostrom has overcome Hobbes ("And Covenants, without the Sword, are but Words, and of no strength to secure a man at all."), as one commentator naively declared when she was awarded both the Nobel prize and the Johan Skytte prize (B. Rothstein' website 2014).

The COP21 project houses lots of reneging opportunities of various sorts, which will become clear as this CPR project moves forward. One major partner has already defected, which may trigger other governments to renege. The only way to control defection in this global CPR is to employ selective incentives, which is what the planned Super Fund could offer, if at all workable. 


\section{The Problematic of Global Warming: Anthropogenic Need of Energy}

To have a firm foundation for understanding the immense increase in $\mathrm{CO}_{2}$ emissions the last two decades, we resort to the Kaya model, linking $\mathrm{CO}_{2}$ : $\mathrm{s}$ with energy and affluence (Kaya \& Yokoburi, 1997). In theories of climate change, the focus is upon so-called anthropogenic causes of global warming through the release of greenhouse gases (GHG). To halt the growth of the GHG: s, of which CO2: s make up about 70 per cent, one must theorize the increase in $\mathrm{CO}_{2}$ : s over time (longitudinally) and its variation among countries (cross-sectionally). As a matter of fact, $\mathrm{CO}_{2}$ : s has very strong mundane conditions in human needs and social system prerequisites. Besides the breading of living species, like Homo sapiens for instance, energy consumption plays a major role. As energy is the capacity to do work, it is absolutely vital for the economy in a wide sense, covering both the official and the unofficial sides of the economic system of a country. Thus, we have this equation format: (E1) Multiple Regression:

$$
Y=a+b_{1} X_{1}+b_{2} X_{2}+b_{3} X_{3}+\cdots+b_{t} X_{t}+u
$$

Thus using the Kaya model for empirical research on global warming, the following anthropogenic conditions would affect positively carbon emissions: (E2) $\mathrm{CO}_{2}: \mathrm{s}=\mathrm{F}(\mathrm{GDP} /$ capita, Population, Energy intensity, Carbon intensity), in a stochastic form with a residual variance, all to be estimated on data from some 59 countries. I make an empirical estimation of this probabilistic Kaya modelthe cross-sectional test for 2014: (E3) $\mathrm{k} 1=0.68, \mathrm{k} 2=0.85, \mathrm{k} 3=0.95, \mathrm{k} 4=0.25$; $\mathrm{R} 2=0.895$. Note: $\mathrm{LN} \mathrm{CO}_{2}=\mathrm{k} 1 * \mathrm{LN}(\mathrm{GDP} /$ Capita) $+\mathrm{k} 2 *$ (dummy for Energy Intensity) $+\mathrm{k} 3$ * (LN Population) $+\mathrm{k} 4$ * (dummy for Fossil Fuels/all) Dummy for fossils 1 if more than $80 \%$ fossil fuels; $\mathrm{k} 4$ not significantly proven to be nonzero, all others are. $(\mathrm{N}=59)$.

The findings show that total $\mathrm{CO}_{2}$ : $s$ go with larger total GDP. First, we see that $\mathrm{CO} 2$ emissions are closely connected with energy consumption, globally speaking. And the projections for future energy augmentation in the $21^{\text {st }}$ century are enormous (EIA, BP, IEA). Figure 1 shows how things have developed since 1990.

To make the dilemma of energy versus emissions even worse, we show in Figure 2 that GDP increase with the augmentation of energy per capita. Decarbonisation is the promise to undo these dismal links by making GDP and energy consumption rely upon carbon neutral energy resources, like modern renewables and atomic energy.

Thus, we arrive at the energy-emissions conundrum: GDP growth being unstoppable requires massive amounts of energy that results in GHC: s or $\mathrm{CO}_{2}$ : $\mathrm{s}$. The only way out of this dilemma is that renewables become so large and effective in a short period of time decarbonisation becomes feasible or likely, not merely desirable. All forms of energy be measured, and these measures are translatable into each other-a major scientific achievement. One may employ some standard sources on energy consumption and what is immediately obvious is the immensely huge numbers involved-see Table 1. 


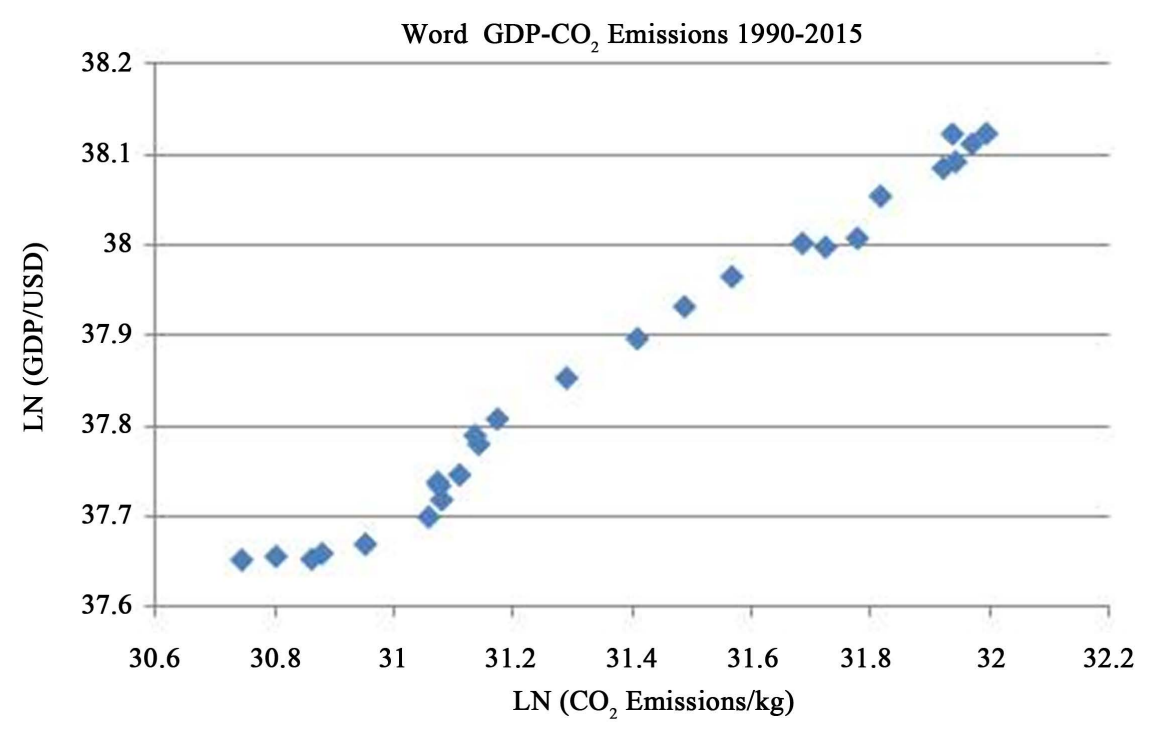

Figure 1. Global GDP-CO $\mathrm{CO}_{2}$ link: $\mathrm{y}=0.4092 \mathrm{x}+25.03, \mathrm{R}^{2}=0.987(\mathrm{~N}=26)$.

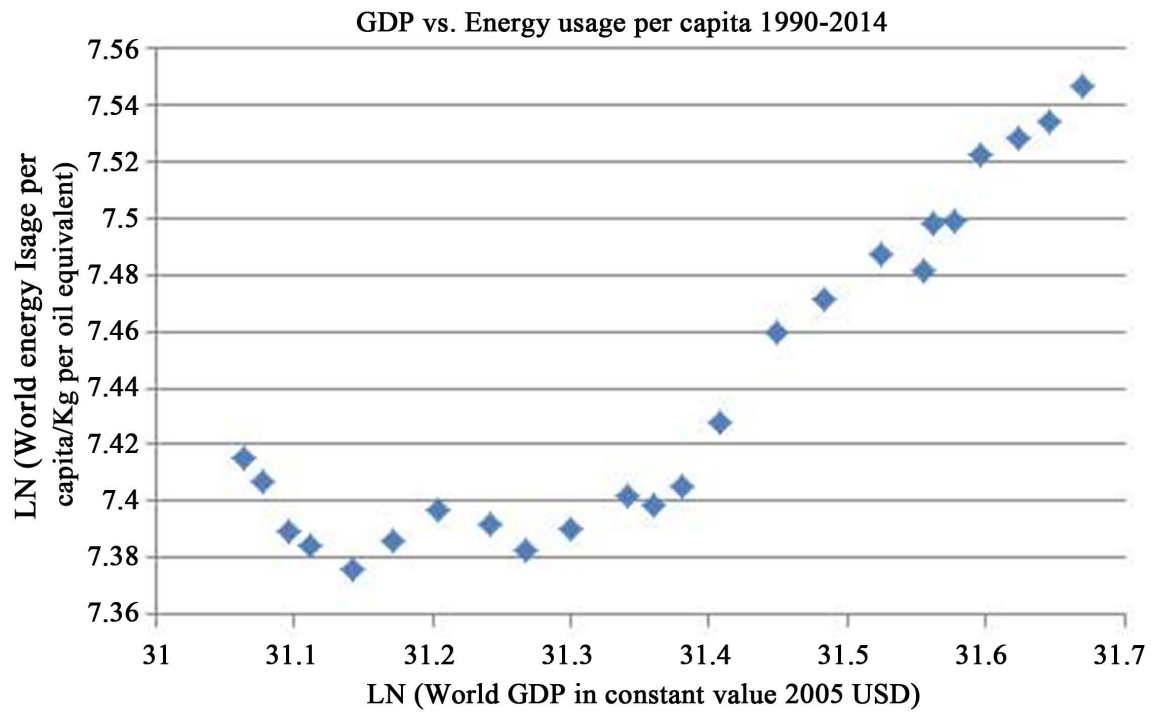

Figure 2. GDP against energy per person $(\mathrm{N}=59)$. Sources: $\mathrm{CO}_{2}$ emission reduction with solar http://www.solarmango.com/in/tools/solar-carbon-emission-reduction,

World Bank national accounts data-data.worldbank.org, OECD national accounts data files, World Resources Institute CAIT Climate Data Explorer-cait.wri.org, EU Joint Research Centre Emission Database for Global Atmospheric Research-

http://edgar.jrc.ec.europa.eu/overview.php, UN framework convention on climate change http://unfccc.int/ghg data/ghg data unfccc/time series annex i/items/3814.php,

International Energy Agency, Paris. Energy Information Administration, Washington, DC. BP Energy Outlook 2016. EU Emissions Database for Global Research EDGAR, http://edgar.jrc.ec.europa.eu/, World Bank Data Indicators, data.worldbank.org, British Petroleum Statistical Review of World Energy 2016.

It is true that a lot is happening with energy and emissions, but one tends to report only the positive news about coal reduction, more efficiency in energy consumption, new solar and wind plants. Sad to say, one bypasses the constantly increasing need for energy, the augmentation of air transportation, more cars 
Table 1. Energy consumption 2015 (Million tons of oil equivalent).

\begin{tabular}{ccc}
\hline & Total & $\%$ \\
\hline Fossil fuels & 11306.4 & 86.0 \\
Oil & 4331.3 & 32.9 \\
Natural Gas & 3135.2 & 23.8 \\
Coal & 3839.9 & 29.2 \\
Renewables & 1257.8 & 9.6 \\
Hydroelectric & 892.9 & 6.8 \\
Others & 364.9 & 2.8 \\
Nuclear power & 583.1 & 4.4 \\
Total & 13147.3 & 100.0 \\
\hline
\end{tabular}

Source: BP Statistical Review of World Energy 2016.

and bigger engines, and first and foremost more human beings! The COP21 call for decarbonisation entails a sharp reduction of fossil fuels up until 2030 in order to stabilize climate change, involving a $30-40$ decrease in $\mathrm{CO}_{2}$ emissions, measured against the 2005 level of emissions.

\section{Solar Power Plants: Global Estimation of Governmentd' Obligations}

Let us first focus upon what this hoped for reduction of fossil fuels implies for the augmentation of renewable energy consumption, here solar power. The use of atomic power is highly contested, some countries closing reactors while others construct new and hopefully safer ones. I here bypass wind power and thermal power for the sake of simplicity in calculations.

Consider now Table 2, using the giant solar power station in Morocco as the benchmark-How many would be needed to replace the energy cut in fossil fuels and maintain the same energy amount, for a few selected countries with big $\mathrm{CO}_{2}$ emissions?

If countries rely to some extent upon wind or geo-thermal power or atomic power, the number in Table 2 will be reduced. The key question is: Can so much solar power be constructed in some 10 years? If not, Hawkins may be right. Thus, the COP23 should decide to embark upon an energy transformation of this colossal size.

Solar power investments will have to take many things into account: energy mix, climate, access to land, energy storage facilities, etc. They are preferable to nuclear power, which pushes the pollution problem into the distant future with other kinds of dangers. Wind power is accused to being detrimental to bird life, like in Israel's Golan Heights. Geo-thermal power comes from volcanic power and sites.

Let us look at the American scene in Table 3.

It has been researched has much a climate of Canadian type impacts upon solar power efficiency. In any case, Canada will need backs ups for its many solar 
Table 2. Number of Ouarzazate plants necessary in 2030 for COP21's GOAL II: Global scene (Note: Average of 250 - 300 days of sunshine used for all entries except Australia, Indonesia, and Mexico, where 300 - 350 was used).

\begin{tabular}{cccc}
\hline Nation & $\begin{array}{c}\mathrm{CO}_{2} \text { reduction } \\
\text { pledge/\% of } \\
\text { 2005 emissions }\end{array}$ & $\begin{array}{c}\text { Number of gigantic } \\
\text { solar plants } \\
\text { needed (Ouarzazate) }\end{array}$ & $\begin{array}{c}\text { Gigantic plants } \\
\text { needed for } \\
\text { 40\% reduction }\end{array}$ \\
\hline United States & $26-28^{\mathrm{i}}$ & 2100 & 3200 \\
China & None $^{\mathrm{ii}}$ & 0 & 3300 \\
EU28 & $41-42$ & 2300 & 2300 \\
India & None & 0 & 600 \\
Japan & 26 & 460 & 700 \\
Brazil & 43 & 180 & 170 \\
Indonesia & 29 & 120 & 170 \\
Canada & 30 & 230 & 300 \\
Mexico & 25 & 120 & 200 \\
Australia & $26-28$ & 130 & 190 \\
Russia & None & 0 & 940 \\
World & N/A & N/A & 16,000 \\
\hline
\end{tabular}

Sources: Paris 2015: Tracking country climate pledges. Carbon Brief,

https://www.carbonbrief.org/paris-2015-tracking-country-climate-pledges, EDGAR v 4.3.2, European Commission, Joint Research Centre (JRC)/PBL Netherlands Environmental Assessment Agency.Emission Database for Global Atmospheric Research (EDGAR), release version 4.3.2. http://edgar.jrc.ec.europe.eu, 2016 forthcomin $\mathrm{CO}_{2}$ Emission Reduction with Solar,

http://www.solarmango.com/in/tools/solar-carbon-emission-reduction.

Table 3. Number of Ouarzazate plants necessary in 2030 for COP21's GOAL II: American scene (Note: Average of 250 - 300 days of sunshine per year was used for Canada, 300 - 350 for the others).

\begin{tabular}{cccc}
\hline Nation & $\begin{array}{c}\mathrm{CO}_{2} \text { reduction } \\
\text { pledge/\% of } \\
2005 \text { emissions }\end{array}$ & $\begin{array}{c}\text { Number of gigantic } \\
\text { solar plants } \\
\text { needed (Ouarzazate) }\end{array}$ & $\begin{array}{c}\text { Gigantic plants } \\
\text { needed for } \\
\mathbf{4 0 \%} \text { reduction }\end{array}$ \\
\hline Canada & 30 & 230 & 300 \\
Mexico & 25 & 120 & 200 \\
Argentina & None $^{\mathrm{ii}}$ & 0 & 80 \\
Peru & None $^{\mathrm{ii}}$ & 0 & 15 \\
Uruguay & None $^{\mathrm{ii}}$ & 0 & 3 \\
Chile & 35 & 25 & 30 \\
\hline
\end{tabular}

power parks, like gas power stations. Mexico has a very favourable situation for solar power, but will need financing from the Super Fund, promised in COP21 Treaty. In Latin America, solar power is the future, especially as water shortages may be expected. Chile can manage their quota, but Argentine needs the Super

${ }^{\mathrm{i}}$ The United States has pulled out of the deal.

${ }^{i i}$ No absolute target.

iii Pledge is above current level, no reduction. 
Fund for sure.

Table 4 has the data for the African scene with a few key countries, poor or medium income.

Since Africa is poor, it does not use much energy like fossil fuels, except Maghreb as well as Egypt plus much polluting South Africa, which countries must make the energy transition as quickly as possible. The rest of Africa uses either wood coal, leading to deforestation, or water power. They can increase solar power without problems when helped financially.

Table 5 shows the number of huge solar parks necessary for a few Asian countries. The numbers are staggering, but can be fulfilled, if turned into the number ONE priority. Some of the poor nations need external financing and technical assistance, like giant India (Ramesh, 2015).

Table 4. Number of Ouarzazate plants necessary in 2030 for COP21's GOAL II: African scene (Note: Average of 300 - 350 days of sunshine per year was used).

\begin{tabular}{cccc}
\hline Nation & $\begin{array}{c}\mathrm{CO}_{2} \text { reduction } \\
\text { pledge/\% of } \\
\mathbf{2 0 0 5} \text { emissions }\end{array}$ & $\begin{array}{c}\text { Number of gigantic } \\
\text { solar plants needed } \\
\text { (Ouarzazate) }\end{array}$ & $\begin{array}{c}\text { Gigantic plants } \\
\text { needed for } \\
\mathbf{4 0 \%} \text { reduction }\end{array}$ \\
\hline Algeria & $7-22^{\text {iv }}$ & 8 & 50 \\
Egypt & None & 0 & 80 \\
Senegal & $5-21$ & 0.3 & 3 \\
Ivory Coast & $28-36^{\text {iv }}$ & 2 & 3 \\
Ghana & $15-45^{\text {iv }}$ & 1 & 3 \\
Angola & $35-50^{\text {iv }}$ & 6 & 7 \\
Kenya & $30^{\text {iv }}$ & 3 & 4 \\
Botswana & $17^{\text {iv }}$ & 1 & 2 \\
Zambia & $25-47^{\mathrm{iv}}$ & 0.7 & 190 \\
South Africa & none & 0 & \\
\hline
\end{tabular}

Table 5. Number of Ouarzazate plants necessary in 2030 for COP21's GOAL II. Asian scene (Note: Average of 250 - 300 days of sunshine was used for Kazakhstan, 300 - 350 days of sunshine per year for the others).

\begin{tabular}{cccc}
\hline Nation & $\begin{array}{c}\mathrm{CO}_{2} \text { reduction } \\
\text { pledge/\% of } \\
2005 \text { emissions }\end{array}$ & $\begin{array}{c}\text { Number of gigantic } \\
\text { solar plants needed } \\
\text { (Ouarzazate) }\end{array}$ & $\begin{array}{c}\text { Gigantic plants } \\
\text { needed for } \\
\mathbf{4 0 \%} \text { reduction }\end{array}$ \\
\hline Saudi Arabia & None & 0 & 150 \\
Iran & $4-12^{\mathrm{ii}}$ & 22 & 220 \\
Kazakhstan & None & 0 & 100 \\
Turkey & 21 & 60 & 120 \\
Thailand & $20-25^{\mathrm{ii}}$ & 50 & 110 \\
Malaysia & None & 0 & 80 \\
Pakistan & None & 0 & 60 \\
Bangladesh & 3.45 & 2 & 18 \\
\hline
\end{tabular}

iv Upper limit dependent on receiving financial support. 
Finally, we come to the European scene, where also great investments are needed, especially as nuclear power is reduced significantly and electrical cars will replace petrol ones, to a large extent (Table 6).

Is there space to build all these solar parks, one may ask. But many, many small houses with solar roofs will also do well. Public buildings and company offices may be run on solar power from their roofs! Innovation is needed everywhere.

As the Keeling curve continues its relentless rise $\left(\right.$ Earth $\left.\mathrm{CO}_{2}\right)$, we must take Hawkins warning about irreversibility seriously. Moving now and up to 2030, according to the COP21's GOAL II for decarbonisation eliminates irreversibility. The solution is solar power parks of Ouarzazate type size. Above is a calculation of what is needed in many countries around the world, taking into account the insights of the research into GDP-energy-emission links. Time has come for halting and reducing $\mathrm{CO}_{2}$ emissions by real implementation and not utopian dreams of a sustainable economy (Sachs, 2015). There is nothing to wait for any longer (Stern, 2015), as the COP23 must set of the promised Super Fund. No time for politicking in the UN any longer (Conca, 2015; Vogler, 2016).

\section{Conclusion: Stephen Hawking's Irreversibility Warning}

The governments of the countries in the world struggle with climate change and its threatening consequences for mankind chiefly by means of the UN mechanism UNFCCC. The upcoming COP23 global meeting, hosted by Fiji must outline how its three 2015 Paris COP21 objectives are to be promoted and implemented by clearly stated means or tools/tasks for international political governance and national political management. It seems now that only a massive replacement of fossil fuels and wood coal by solar and/or wind power can save mankind from the threat of global warming. How will the governments go about this formidable challenge, relying upon powerful market incentives for the demand and supply of solar energy (Barry, 1982; Hayek, 1991)?

Sooner or later, as global warming continues, outcomes like the following arrive, here with a few examples of already occurring disasters:

Table 6. Number of Ouarzazate plants necessary in 2030 for COP21's GOAL II: European scene (Note: Average of 250 - 300 days of sunshine per year was used).

\begin{tabular}{cccc}
\hline Nation & $\begin{array}{c}\mathrm{CO}_{2} \text { reduction } \\
\text { pledge/\% of } \\
2005 \text { emissions }\end{array}$ & $\begin{array}{c}\text { Number of gigantic } \\
\text { solar plants needed } \\
\text { (Ouarzazate) }\end{array}$ & $\begin{array}{c}\text { Gigantic plants } \\
\text { needed for } \\
40 \% \text { reduction }\end{array}$ \\
Germany & $49^{\mathrm{v}}$ & 550 & 450 \\
France & $37^{\mathrm{v}}$ & 210 & 220 \\
Italy & $35^{\mathrm{v}}$ & 230 & 270 \\
Sweden & $42^{\mathrm{v}}$ & 30 & 30 \\
\hline
\end{tabular}

${ }^{\mathrm{EU}}$ joint pledge of $40 \%$ compared to 1990. 
a) Huge land losses along the costs (Bangladesh, Vietnam);

b) Too high temperatures for men and women to work outside with constant need of air conditioning increasing climate change (Middle East, South East Asia);

c) Food production decline (Africa);

d) Fish harvest decrease (Pacific Ocean, Atlantic, Indian Ocean);

e) Droughts and starvation (Africa);

f) Lack of fresh water supply (India, Africa, USA);

g) Drying up of rivers, affecting electricity supply (South America, India);

h) Ocean acidification and species extinction (Australia, East Africa);

i) Highly volatile climate with tremendous damages from flooding and storms or hurricanes and tornados (Pakistan, Sri Lanka, Bangladesh, Thailand, etc.);

j) Extremely violent forest fires (Portugal, US, Canada, Indonesia);

k) Damages to the Poles with sea level rise and diminution of glaciers with water shortage;

1) Beginning of the unfreezing of the global permafrost.

This list is far from the complete or exhaustive. One could even mention worse outcomes, like the transformations of warm and cold currents in the oceans (Gulf Stream, North Atlantic Stream).

\section{References}

Arrhenius, S. A. (1961). Chambers's Encyclopædia. London: George Newnes.

Barry, B. (1982). The Tradition of Spontaneous Order. Literature of Liberty, 10, 7-58.

British Petroleum (2016). BP Energy Outlook 2016. London: British Petroleum.

British Petroleum (2016). Statistical Review of World Energy 2016. London: British Petroleum.

$\mathrm{CO}_{2}$ Emission Reduction with Solar. http://www.solarmango.com/in/tools/solar-carbon-emission-reduction

Conca, K. (2015). Un Unfinished Foundation. The United Nations and Global Environmental Governance. Oxford: Oxford University Press. https://doi.org/10.1093/acprof:oso/9780190232856.001.0001

Dutta, P. L. (1999). Strategies and Games. Cambridge, MA: MIT Press.

EDGAR v 4.3.2, European Commission, Joint Research Centre (JRC)/PBL Netherlands Environmental Assessment Agency. Emission Database for Global Atmospheric Research (EDGAR), Release Version 4.3.2. http://edgar.jrc.ec.europe.eu

Energy Information Administration. Washington, DC.

EU Emissions Database for Global Research EDGAR. http://edgar.jrc.ec.europa.eu/

EU Joint Research Centre Emission Database for Global Atmospheric Research. http://edgar.jrc.ec.europa.eu/overview.php

Hayek, F. A. (1991). The Fatal Conceit: The Errors of Socialism. Chicago, IL: The University of Chicago Press.

International Energy Agency. Paris.

Kahn, H. (1962). Thinking about the Unthinkable. Far Hills, NJ: Horizon Press.

Kaya, Y., \& Yokoburi, K. (1997). Environment, Energy, and Economy: Strategies for Sustainability. Tokyo: United Nations University Press. 
OECD National Accounts Data Files.

Ostrom, E. (1990). Governing the Commons. Cambridge: Cambridge University Press. https://doi.org/10.1017/CBO9780511807763

Paris 2015: Tracking Country Climate Pledges. Carbon Brief. https://www.carbonbrief.org/paris-2015-tracking-country-climate-pledges

Popper, K. R. (1962). Conjectures and Refutations. London: Routledge.

Pressman, J., \& Wildavsky, A. (1973, 1984). Implementation. Berkeley, CA: University of Cal Press. https://doi.org/10.1093/acprof:oso/9780199457526.001.0001

Ramesh, J. (2015). Green Signals: Ecology, Growth and Democracy in India (2015). Oxford: Oxford University Press. https://doi.org/10.7312/sach17314

Sachs, J. D. (2015). The Age of Sustainable Development. New York: Columbia University Press.

Simon, J. (2002). A Life against the Grain. Piscataway, NJ: Transaction Publisher.

Stern, N. (2007). The Economics of Climate Change. Oxford: Oxford University Press. https://doi.org/10.1017/CBO9780511817434

Stern, N. (2015). What Are We Waiting for? Cambridge, MA: MIT Press.

UN Framework Convention on Climate Change. http://unfccc.int/ghg data/ghg data unfccc/time series annex i/items/3814.php

Vogler, J. (2016). Climate Change in World Politics. London: Macmillan Palgrave. https://doi.org/10.1057/9781137273413

Wildavsky, A. (1997). Is It Really True? Cambridge, MA: Harvard University Press.

World Bank Data Indicators. data.worldbank.org

World Bank National Accounts Data. http://data.worldbank.org

World Resources Institute CAIT Climate Data Explorer. http://cait.wri.org

Submit or recommend next manuscript to SCIRP and we will provide best service for you:

Accepting pre-submission inquiries through Email, Facebook, LinkedIn, Twitter, etc. A wide selection of journals (inclusive of 9 subjects, more than 200 journals) Providing 24-hour high-quality service User-friendly online submission system Fair and swift peer-review system Efficient typesetting and proofreading procedure Display of the result of downloads and visits, as well as the number of cited articles Maximum dissemination of your research work

Submit your manuscript at: http://papersubmission.scirp.org/

Or contact ojps@scirp.org 